DOI: $10.22363 / 2312-9182-2019-23-1-83-97$

\title{
The Realization of Impoliteness in Arguments between the Democrats and Republicans over the Government Shutdown Issue in the US
}

\author{
Minoo Alemi, Ashkan Latifi \\ Islamic Azad University, West Tehran Branch, \\ Simaye Iran St., 1467686831, Tehran, Iran \\ Sharif University of Technology \\ Azadi Ave., 11365-11155, Tehran, Iran
}

\begin{abstract}
The present research is intended to illustrate how linguistic features of impoliteness are manifested in the debates between two of the main American political parties, Republicans and Democrats, in 2013 government shutdown issue. The research questions sought to analyze the impoliteness strategies each party employed to aggravate or attack the face of the opposing party. The study was conducted by performing qualitative discourse analysis based upon the theoretical framework of Culpeper's (1996) super strategies and Bousfield's (2008) off-record impoliteness. The data consisted of the transcripts of the speeches of the two parties' members all through September, 20, to October, 16, 2013. The study primarily managed to elicit eight major impoliteness strategies in this corpus. The analysis chiefly revealed that both parties used all the strategies in relatively similar frequencies to induce their opponents to act upon their preferences. Challenges, dissociating from the other, sarcasm/mock politeness, and seeking disagreement/avoid agreement were among the most commonly used impoliteness strategies in the debates. In addition, as the ChiSquare test disclosed, the two parties did not differ from one another in a statistically meaningful way in their total use of impoliteness strategies. In conclusion, our study showed that there seems to be a relatively similar pattern of use of impoliteness strategies by these two parties over the aforementioned issue which can be attributed to the demands of political discourse.
\end{abstract}

Keywords: impoliteness, political discourse analysis, face threatening acts, U.S. government shutdow, healthcare, Obamacare

\section{Проявления невежливости в дебатах между республиканцами и демократами по вопросу о приостановлении деятельности государственных органов США}

\author{
Мину Алеми, Ашкан Латифи \\ Исламский университет Азад \\ Simaye Iran St., 1467686831, Тегеран, Иран \\ Технологический университет им. Шарифа \\ Azadi Ave., 11365-11155, Тегеран, Иран
}

Цель настоящего исследования - продемонстрировать, каким образом лингвистические показатели невежливости реализуются в дебатах между двумя основными американскими партиями - Республиканской и Демократической. Изыскания направлены на анализ угрожающих лицу стратегий 
невежливости, которые использовались каждой партией в дебатах по приостановлению деятельности государственных органов в 2013 г. В процессе исследования использовался качественный дискурсанализ, основанный на теоретической модели супер-стратегий Дж. Кальпепера (Culpeper 1996) и модели невежливости Д. Баусфилда (Bousfield 2008). Материалом исследования послужили транскрипты речей представителей вышеуказанных партий, зафиксированных в период с 20 сентября по 16 октября 2013 г. Было выделено восемь ведущих стратегий невежливости, которые, согласно проведенному анализу, использовались с относительно одинаковой частотностью для того, чтобы побудить оппонентов к действиям, предпочтительным для ораторов. Чаще всего использовались стратегии: вызов, разобщение, сарказм/насмешка, разлад/отсутствие согласия. Как показал тест Chi-Square, в поведении представителей двух партий не наблюдалось существенных количественных различий в использовании стратегий невежливости. Был сделан вывод о том, что сходные закономерности использования стратегий невежливости обеими партиями могут объясняться требованиями политического дискурса.

Ключевые слова: невежливость, политический дискурс-анализ, угрожающие лииу акты, приостановление деятельности государственных органов, здравоохранение, Оbатасате

\section{INTRODUCTION}

As Cook (2011) argues, at first discourse analysis was serving descriptive linguistics and structuralism during the 1950s and 1960s and aimed at an investigation of the text beyond sentence-level in terms of cohesion of the interrelationships present within the text; however, influenced by Halliday's Systemic-Functional linguistics and Hymes' theory of communicative competence, discourse analysis managed to transcend the view of language as a self-contained structure held dear by structuralists and step in the realms of authentic language use in the social milieu.

According to Pelinka (2007), language must be analyzed and treated as a political phenomenon and politics as a discursive practice. Evidently, political discourse analysis (PDA) as an offshoot of 'discourse analysis' (DA) mainly concentrates upon the analysis of political discourse. As Dunmire (2012: 735) puts it, "PDA comprises inter- and multidisciplinary research that focuses on the [linguistic] and discursive dimensions of political text and talk and on the political nature of discursive practice". The studies which took discourse analysis approach as a method of investigation in political issues are abundant (e.g., Campell and Jamieson 1990, Maynard 1994, Chilton 2002, Oddo 2011, Gornostaeva 2016, Mirzaie, Eslami and Safari 2017, Alemi, Tajeddin and Rajabi Kondlaji 2018). However, research within the framework of impoliteness in political discourse is still young and in need of further exploration.

One of the features of political discourse that has attracted the attention of political discourse analysts is the use and manipulation of (im)politeness strategies by statesmen/stateswomen and other political figures in their verbal political expressions; however, debates over the concept of (im)politeness are numerous, sometimes vague, and controversial. In Watts' precise and concise words "(im)politeness is a term that is struggled over at present, has been struggled over in the past and will, in all probability, continue to be struggled over in the future" (2003: 9).

Acknowledging these points, difficulties, and the need for further research in the use and manipulation of (im)politeness strategies in political discourse, this paper attempted to conduct a discourse analysis of the US Democratic and Republican politicians' utilization of impoliteness strategies during their debates on the issues of healthcare and U.S. 
government shutdown in 2013. Using Culpeper's (1996) and Bousfield's (2008) framework, this study investigated how the members of each of these political parties manifested impoliteness in their speech to attack the other Party's face.

\section{REVIEW OF THE RELATED LITERATURE}

\subsection{Political Discourse Analysis (PDA)}

Although the analysis of political discourse is scarcely new, the findings and theoretical premises of cognitive linguistics (mainly embarked upon by Noam Chomsky) linking the mental capacity of language with other mental capacities let political and social cognition be taken account of in the discipline of linguistics (Chilton 2004). In addition, as a result of a turn in linguistics resulting in Critical Linguistics and also interdisciplinary works among a variety of disciplines, such as linguistics, political science, sociolinguistics, critical theory, cognitive linguistics, rhetoric, generative linguistics, etc., many scholars managed to contribute to the theoretical richness of PDA as an offshoot of discourse analysis (see Chilton 2004, Dunmire 2012).

According to van Dijk (1997), PDA can either refer to a political approach to discourse analysis or an analysis of political discourse. Obviously, the present study was concerned with the latter. The scope of political discourse depending upon the scholar's viewpoint can be either limited to the discourse produced by political figures (a view held by van Dijk 1997) or the everyday life's discursive practices of any individual (a view taken by Okulska and Cap 2010) whose life is in one way or another politicized as a result of living in a society imbued with politics. PDA with resort to the disciplines mentioned and discussed above and the theoretical toolkit provided by them analyzes political texts for a variety of end(s), for example, laying bare a political figure's use of persuasive strategies (e.g., Alemi, Latifi and Nematzadeh 2018), discourse and agency (e.g., Bleiker 2003), metaphor's manipulation impact in political discourse (Zaripov 2014), etc. As to the current study, an investigation of impoliteness in political discourse is the end for which PDA is carried out.

\subsection{Politeness and Impoliteness}

The concept of politeness was initially introduced and theorized by Brown and Levinson (1987) and grounded in Grice's (1975) maxims and Goffman's (1967) concept of face. As Holmes (1995) argues, politeness involves both concern for others' feelings as well as a distancing behavior which is non-imposing. In general terms, politeness refers to any behavior that tries to save the face of the addressee; according to this definition, those behaviors and strategies that are in contrary, i.e. attack the addressee's face and thus cause social dissonance, are impolite (Culpeper, Bousfield and Wichmann 2003). Although Brown and Levinson's theory covers face, it falls short of dealing with contexts in which threatening face does not play the primary role or the context within which the explicit behaviors which are unmarked and appropriate do not necessarily mean polite (Locher and Watt 2005).

As an attempt at moving beyond the formalist tendencies in Brown and Levinson's theory, Culpeper (2005) adds the notion of intentionality to the act of impoliteness as one 
of the important conditions for considering an utterance impolite. In addition, according to Holmes, Marra and Schnurr (2008), Social norms highlight the significance of social standards and the listener's perception of them but disregard the role of intentionality which is another dimension of impoliteness. As they define them, social norms are "linguistic behavior[s] assessed by the hearer as threatening her or his face or social identity, and infringing the norms of appropriate behavior that prevail in particular contexts and among particular interlocutors, whether intentionally or not" (Holmes et al. 2008: 196).

Resorting to the notion of community of practice, Mills (2003) also believes that impoliteness can solely be understood and analyzed pragmatically once regarded in reference to group/community understanding of (an) utterance(s), and additionally in terms of the ongoing discourse strategies of the utterer(s). Furthermore, Holmes et al. (2008) postulate that the perception of the hearer is an additional dimension of impoliteness as well. As a sum of these theoretical stands, Culpeper's (2005) definition includes both the hearer's perception and the concept of intentionality. In other words, for Culpeper, impoliteness has taken place when the addresser deliberately mitigates the addressee's face, or when the addressee construes the addresser's behavior as a purposeful attack on her face, or a mixture of both conditions.

\subsection{Research on Impoliteness in Political Discourse}

As Culpeper (2013) argues, theoretically speaking, many theories, specifically in interactional sociolinguistics and pragmatics, are aimed at studying socially cooperative interactions and have given inadequate attention to anti-social ones; however, such interactions are worth studying in that, for example, impoliteness, contrary to being generally assumed as the repugnant part of language, is indeed often creative. In recent years, research within the framework of '(im)politeness' has been enriched in many areas of interest (see Jamet and Jobert 2013) and, of course, in different political genres (e.g., P'erez de Ayala 2001, Garcia-Pastor 2002, Bolívar 2005, Harris, Grainger and Mullany 2006, Maalej 2012, Toddington 2015). Although studies of impoliteness have been carried out on a variety of discourses (e.g., Homles and Schnurr 2005, Lorenzo-Dus 2009, Murphy 2014, Mirhosseini, Mardanshahi and Dowlatabadi 2017, de Marlangeon 2018), there still seems to be an insufficient amount of impoliteness research on political discourse. Consequently, the present study was trained upon the realization of impoliteness in the arguments between Democrats and Republicans over the US government shutdown issue in the US in 2013.

\section{THE SITUATION}

\subsection{The US Government}

According to the mission set for the United States Congress (2018), as the bicameral legislature of the U.S. federal government, the Congress consists of the House of Representatives, whose major power is to initiate and pass the legislation, and the Senate as the stabilizing force. In contrast to the (bicameral) parliamentary governments, the two branches in federal systems such as the United States possess equal competitive powers. 
The advocates of bicameralism believe that since different parts of a chamber have powers that influence and manage the other chamber, this will prevent the instigation of dogmatic cliques or the passage of immature legislation into the law. On the other hand, the opponents of the model argue that when the powers of two branches are equal, the bicameral model may get caught in deadlock in certain circumstances (Bicameralism 2018).

The United States of America includes two political parties in chief, the Republican Party as well as its older challenger the Democratic Party. In contrast to the Republican Party which sustains an American Conservatism position based upon the principles of classical liberalism (Grigsby 2008, Arnold 2009, Levy 2006), the Democrats give support to modern liberal policies in the contemporary American political discourse (Farmer 2006). This kind of social liberalism endorses government programs such as education and health care (Mikis and Meliur 2005).

Not only was the former US President, Barack Obama, a Democrat, but also this Party held a majority of the Senate seats in 113th US Congress elections in 2012. However, a majority of seats was held by Republicans in the House of Representatives then. As a result of this contradiction in the leadership of the House of Representatives and the Senate, the United States entered a crisis over the issue of health care (Government shutdowns in the United States 2018).

\subsection{The Healthcare Issue}

In 2004 Institute of Medicine (IOM) stated that the population in the United States is one of the few industrialized nations that do not have an access to healthcare (Institute of Medicine 2004). According to a Harvard study, the 44,800 excess deaths in the US were attributable to the lack of health insurance (Wilper et al. 2009). And compared to other industrialized high-income nations, the United States fares worst in nine vital health domains which can cause mortality, such as disability, obesity, diabetes, chronic lung disease, heart disease, HIV and AIDS, etc. (National Research Council, \& Committee on Population 2013).

On October 1, 2013, as a result of a funding gap caused by the incongruity of the two chambers of the Congress over an appropriations continuing resolution for fiscal year, 2014, the United States federal government brought its regular operations to a standstill. The deadlock rooted on a bill passed by the Republicans in the House of Representatives on September 20, 2013 (Espo 2013), which included provisions that would defund the Affordable Care Act (ACA) commonly known as Obamacare. Originally, the major objectives of ACA were to increase the quality and affordability of health insurance, lower the costs of health care for individuals and the government, decrease the uninsured rate by expanding public and private insurance coverage, etc. (Public Law 2010).

The opposition of ACA mostly comprised of major conservative-led groups including congressional and many state Republicans, the Tea Party Movement, and a number of small business organizations that assumed that the law would cause problems to health plans, increase costs for new insurance standards, and run deficits (Peters 2011). 
On October 17, after 16 days of controversial and intense arguments between the two legislative houses, an interim compromise bill was eventually signed into law by President Obama and the government's regular operations were resumed (Cohen 2013).

\section{RESEARCH QUESTIONS}

Two research questions were formulated in the light of the preceding discussions.

1. What are the realizations of impoliteness in the arguments between the Democrats and Republicans over the US government shutdown in 2013 ?

2. Is there any significant difference between the two parties regarding the use of impoliteness strategies in these arguments?

\section{METHOD}

\subsection{The Corpus}

The materials used in this study were the video clips of the Democrats' and Republicans' speeches on different occasions including press conferences, briefings and, interviews related to the US government shutdown issue from September 20 through October 16, 2013.

The selected corpus for this study lasts about 240 minutes of ongoing speech (120 minutes of which are the video clips of Republican candidates and the other 120 minutes belong to Democratic candidates'). They were downloaded from C-span.com and carefully transcribed.

\subsection{Analytical Framework}

The framework employed in this study was based upon Bousfield's (2008) description of the realizations and strategies of impoliteness, generally adopted from Culpeper's outline (1996). Furthermore, in this study, the concept of impoliteness used by the researchers was a second order notion (see Watts 2003). Hence, in line with Culpeper (2005), the researchers conceptualized impoliteness as the speaker's deliberate face aggravating or verbal attack which is recognized as an intentional face mitigating behavior by the hearer.

As stated by Culpeper (1996), there are five super strategies for performing a Face Threatening Act (FTA). These five super strategies are (Culpeper 1996: 356).

1. Bald on record impoliteness: the face threatening act (FTA) is performed in a direct, clear, unambiguous and concise way where face is not irrelevant.

2. Positive impoliteness: the use of strategies designed to damage the addressee's positive face wants.

3. Negative impoliteness: the use of strategies designed to damage the addressee's negative face wants.

4. Sarcasm or mock politeness: the FTA is performed with the use of politeness strategies that are obviously insincere, and thus remain surface realizations.

5. Withhold politeness: the absence of politeness work where it would be expected.

Drawing upon these five super strategies, Culpeper (1996: 357-358) suggests a number of negative (e.g., Frighten; Condescend, scorn or ridicule; Explicitly associate 
the other with a negative aspect; Call the other name; etc.) and positive (e.g., Ignore, snub the other; Disassociate from the other; Use inappropriate identity markers; Seek disagreement; etc.) output strategies eight of which were used by political members of these two parties in their arguments (see section 6).

\section{RESULTS AND DISCUSSION}

\subsection{Research Question One}

Using Bousfield's (2008) realizations of impoliteness based upon Culpeper (1996), the analysis of face aggravating strategies in this study revealed eight impoliteness strategies in the debates between the Democrats and Republicans over the issues aforementioned. Table 1. demonstrates the frequency of these strategies that each party employed.

Table 1

The frequency of impoliteness strategies

\begin{tabular}{|l|c|c|}
\hline \multicolumn{1}{|c|}{ Frequency } & Republicans & Democrats \\
\hline Disassociate from the other & 18 & 16 \\
\hline Use inappropriate identity markers & 9 & 5 \\
\hline Seek disagreement/avoid agreement & 15 & 20 \\
\hline Threaten/Frighten & 3 & 1 \\
\hline Scorn or ridicule & 10 & 8 \\
\hline Explicitly associate the other with a negative aspect & 12 & 12 \\
\hline Sarcasm/mock politeness & 16 & 19 \\
\hline Challenges & 27 & 32 \\
\hline Total & 110 & 113 \\
\hline
\end{tabular}

This comparison displayed that the frequency of the strategies was relatively congruent between the two parties. The most employed strategy by both groups was the strategy of challenges, and the threaten/frighten strategy had the lowest frequency of all. The following displays a number of examples attributed to each of these strategies pursued by the speakers. However, in the process of analyzing the data, it became evident that the strategies realized in political discourse are by no means distinct from each other. Typically, they merge together or sometimes several of them are combined in order to inflict the maximum impact.

\subsubsection{Disassociate from the other}

REP. Cathy McMorris Rodgers (R), Washington:

"House Republicans do not want to shut down the government. The American people don't want the government shut down. They also don't want Obamacare."

This impolite strategy is implemented when a participant refuses to be associated with others and avoids having a common ground. It is used here as the speaker considers the American people to be in total agreement with the Republican Party, while rejecting the Democrats over the healthcare issue. The speaker purposefully uses the term "Obamacare" to imply that not only the Republicans but the majority of the Americans are against the President's plans which are affiliated with the Democratic Party's principles. 


\subsubsection{Use inappropriate identity markers}

REP. Nancy Pelosi (D), California, Minority Leader:

"This crisis could be over in hours, if the speaker of the Republicans would just take yes for an answer, instead of continuing to be the Party of No. On 7 different occasions, the Republican Party of No has not taken yes for an answer of Democrats, offering motions on the Senate past Republican number of 986."

The speaker utilizes the identity marker "the Republican Party of No" to address the Republicans. This term of address is particularly repeated twice. Flouting the maxims of quality and manner, the speaker forms an implicature to put the blame of the shutdown on the Republicans by using an inappropriate identity marker. But it should be also mentioned that sarcastic utterances included in sarcasm strategy (see Culpeper 1996, 2005) appear to be used and merged with other strategies such as use inappropriate identity markers.

\subsubsection{Seek disagreement/avoid agreement}

REP. Nancy Pelosi (D), California, Minority Leader:

"Our question was, Mr. Speaker, why are you not appointing conferees to the budget conference. His statement was 'under the rules if you appoint conferees and after 20 legislative days there is no agreement, the minority has a right to offer motions to instruct'; which become politically motivated bombs to throw up on the house floor. So, to be frank with you, we are following what I would describe as a regular order. Well to be frank with him, the regular order is not how he defines it. It is what the regular order is of the house."

As an example, the speaker's statement "to be frank with him the regular order is not how he defines it" shows the Democrat speaker's substantial disagreement with the actions of the Republican speaker of the House. She further continues that the regular order is the regular order of the House, and by stating this vague statement she violates the maxim of manner. That is, she implies that although Democrats are committed to the orders (which is a vague term here), the Republicans refuse to follow them. Evidently, the speaker employs the avoid agreement strategy by selecting a sensitive and vague topic and elaborating upon it with aiming at disagreement.

\subsubsection{Threaten/Frighten}

Rep, Lynn Jenkins (R), Kansas

"I've been reminded the last few weeks about Albert Einstein's definition of insanity; doing the same thing over and over again and expecting different results. The only thing more irresponsible or more insane than the President letting us default on our debt, would be the President's demand that we increase the Federal debt ceiling without addressing our nation's spending problem. This nation's spending addiction has finally caught up with us. Today each one of us owes over 53000 dollars in Federal debt. This is not sustainable and we need to start addressing it now. If we don't start now when will we ever address our debt? When it hits 18 trillion, 19 trillion? Or do we wait until our economy totally collapses?"

According to Culpeper (1996), threaten/frighten is an impolite strategy in which the participant prompts to show a destructive incident is imminent. In this example, in order to influence the audience, the speaker chooses to warn the audience that the 
President's decisions are "insane" and "irresponsible". The last statement is a blend of the threaten/frighten and the challenges strategies since the speaker tries to frighten the audience that the detrimental impacts of the Democratic policies on the future economy are impending.

\subsubsection{Condescend, scorn or ridicule}

REP. Eric Cantor (R), Virginia, Majority Leader:

"You know, up until today we had 57 Democrats that supported bipartisan bills to relieve the pain of this shutdown. And you have to ask yourself, now with the unanimous vote that we just saw for federal employees, if it so important to ease the pain for them, what about the vets? Did the Democrats not feel it's important to make sure the pain is eased on them? What about the sick children that need access to clinical trials? Is it not as important to ease the pain of the shutdown for them? Or is it just the federal employees that the Democratic minority thinks is important?"

The maxim of quality is flouted in "the Democratic minority" since the Democratic Party actually comprises the majority of the U.S. government, including the President and the Senate. The speaker uses this implicature to scorn the Democratic Party and play down their influence. That is, although they have the majority of the government leadership, they do not represent the majority of the American people.

\subsubsection{Explicitly associate the other with a negative aspect}

REP. Lynn Jenkins, (R), Kansas, 2nd District, Oct. 5:

"Contrary to what the President and those in the White House believe, there are no winners when the Federal government shuts down. There are real consequences. And the house did not want this shutdown. And we believe my way or the highway mentality cannot be sustained."

In this example, the speaker's statements make for a strong disapproval of the Democratic Party's actions by explicitly associating their viewpoint to "my way or the highway mentality" which is a negative expression. She employs this to communicate the idea that "the Democrats believe they are always right and anyone who does not agree with them has no business with them'. In other words, the speaker uses an impolite strategy to associate the other with negative characteristics such as inflexibility and stubbornness.

\subsubsection{Sarcasm/mock politeness}

REP Kevin McCarthey (R), California, Majority Whip:

"So let's recap what's gone on this week: on Wednesday the House passed Opening the National Parks, Funding the NIH, and Local Funding for D.C. On Thursday, the House passed: Funding our Guard and reserves, funding our Veterans. Friday we passed the National Emergency Disaster Recovery Act; Friday the Nutrition Assistant for Low-Income Women and Children. And today, as the leader said, we made sure all the federal employees and also made sure the military was able to have service on Sunday. The Senate, Wednesday: no roll call votes. Thursday: no roll call votes. Friday: no roll call votes. But they have worked. They did adopt the national, chess week. This has got to stop." 
Using insincere politeness strategies is the demonstration of sarcasm when they remain surface realizations (Culpeper 1996). In order to be effective, sarcasm needs something more than insincere impoliteness; in other words, it requires context (Bousfield 2008). The expression "they have worked" seems to be polite at a first glance, but regarding the preceding statements that the Democrats had no roll call votes during the week, it is clear that the maxim of quality is violated and the speaker tries to imply that in spite of all the actions that Republicans have taken throughout the week, Democrats have actually done nothing.

\subsubsection{Challenges}

REP. Cathy McMorris Rodgers (R), Washington:

"We were here late last night almost midnight taking action after midnight to ensure that government would be kept open. Now today we see where Senate doors are shut. Senator Harry Reid says it is inevitable that the government is going to shut down if the Senate doesn't act. It may be inevitable but we are here to say that the Senate needs to act. Why are they waiting? Why aren't those doors open?"

According to Bousfield (2008), challenges are always inflicted in question form. In this statement, Rep. McMorris mounts two challenges to the Democratic Party. They are "Why are they waiting?" and "Why aren't those doors open?". Particularly in the first question, the Democrats are explicitly challenged.

\subsection{RESEARCH QUESTION TWO}

In order to answer research question two, the Chi-Square test was run to specify whether or not the difference between the overall frequency of the impoliteness strategies used by each of the two parties was significant. However, as two cells displayed expected count less than five and the sample size was small, the Likelihood Ratio was preferred to the Pearson Chi-Square and reported. According to Hinton, Brownlow, McMurray, and Cozens (2004: 282), "[t]he Likelihood Ratio is an alternative test to the chi-square employing a different method. Normally we use the chi-square result but this statistic is sometimes preferred when the sample size is small."

As Table 2 shows, the null hypothesis cannot be rejected because $\chi^{2}=3.9, \mathrm{df}=7$, $\mathrm{P}>0.05$. Accordingly, the difference between the overall frequency of the impoliteness strategies implemented by the two parties in their arguments proved non-significant. In sum, accordingly, the two parties followed an overall similar pattern in their use of impoliteness strategies in their pursuit of their political ends which can be the result of an overall established norm of conduct in political discourse and its attributed genres.

Table 2

Chi-Square Tests

\begin{tabular}{|l|c|c|c|}
\hline & Value & df & Asymp. Sig. (2-sided) \\
\hline Pearson Chi-Square & $3.8^{\mathrm{a}}$ & 7 & .79 \\
\hline Likelihood Ratio & 3.9 & 7 & .79 \\
\hline Linear-by-Linear Association & .7 & 1 & .4 \\
\hline N of Valid Cases & 223 & & \\
\hline
\end{tabular}

a. 2 cells (12.5\%) have expected count less than 5 . The minimum expected count is 1.97. 


\section{CONCLUSION}

The incentive behind this research was to analyze a political text applying the impoliteness frameworks of Bousfield (2008) and Culpeper (1996). However, it should be noted that analyzing the realizations of impoliteness in political discourse is not at all a straightforward task since politicians are strictly restricted in adopting many of the on-record impoliteness strategies. Besides, the instances of use of impoliteness strategies are not clear-cut and may overlap. Taking notice of these issues, this study collected a sample of impoliteness realizations which emerged in the debates between the two American political parties (the Democratic and Republican Parties) over the U.S. government shutdown issue of 2013.

Based upon the models discussed, eight major impoliteness strategies which were realized in this research comprised:

1. Disassociate from the other

2. Use inappropriate identity markers

3. Seek disagreement/avoid agreement

4. Threaten/Frighten

5. Condescend, scorn or ridicule

6. Explicitly associate the other with a negative aspect

7. Sarcasm/mock impoliteness

8. Challenges

Statistical analysis revealed that both parties did not significantly differ in their use of impoliteness strategies in the pursuit of their political objectives in the issue aforementioned. In addition, the high frequency of the challenges strategy showed that both parties faced their opponents by questioning their plans and policies. Besides, the Republicans employed the disassociate from the other strategy most frequently to assert that the Democratic Party's policies towards the healthcare issue were different from Republicans'. Furthermore, the Democrats employed the seek disagreement/avoid agreement as their second most frequent strategy to boldly highlight the issues that caused the conflict with their opponent in the first place. As expected, the low use of the threaten/ frighten strategy can be the result of the codes of conduct and the disallowance of 'explicit threat' in this political context. Notwithstanding, it is suggestive that the third most frequently used impoliteness strategy for both parties turned out to be sarcasm/ mock impoliteness. As if the cathexis of disallowed strategies was given vent to in sarcasm/mock impoliteness. In brief, our study showed that the two political parties concerned acted within a relatively similar framework vis-à-vis impoliteness strategies that can be attributed to the demands and standards of the genre of political debates and live speeches within political discourse in the US. The presence/absence and the high/low instances of use of certain impoliteness strategies suggest that such debates take place and are held within the implicitly/explicitly agreed upon structural limits and constraints of the political genre of 'debate'. This is in need of further research though.

Since there is a dearth of impoliteness research on political discourse, launching investigations into impoliteness strategies in other political genres is warranted so as to examine form and function of impolite linguistic features in a broader scope and 
perspective of political discourse. Withal, the findings of this study can be conducive to expand the readers' knowledge about linguistic impoliteness strategies in political situations. They may also be practical in certain areas of political studies such as political power, persuasion, assertion, etc.

(C) Minoo Alemi, Ashkan Latifi, 2019

\section{REFERENCES}

Alemi, M., Latifi, A., \& Nematzadeh, A. (2018) Persuasion in political discourse: Barak Obama's presidential speeches against ISIS. Russian Journal of Linguistics, 22(2), 278-291.

Alemi, M., Tajeddin, Z., \& Rajabi Kondlaji, A. (2018) A discourse-historical analysis of two Iranian presidents' speeches at the UN General Assembly. International Journal of Society, Culture \& Language, 6(1), 1-17.

Arnold, N. S. (2009) Imposing values: an essay on liberalism and regulation. Florence: Oxford University Press.

Bicameralism (n.d.) In Wikipedia. Retrieved May 25, 2018, from https://en.wikipedia.org/wiki/ Bicameralism.

Bleiker, R. (2003) Discourse and human agency. Contemporary Political Theory, 2(1), 25-47.

Bolívar, A. (2005) Dialogue and confrontation in Venezuelan political interaction. Aila Review, $18(1), 3-17$.

Bousfield, D. (2008) Impoliteness in Interaction. Philadelphia and Amsterdam: John Benjamins.

Brown, P. \& Levinson, S. C. (1987) Politeness: Some universals in language usage. Cambridge: Cambridge University Press.

Chilton, P. (2002) Do something! Conceptualising responses to the attacks of 11 September 2001. Journal of Language and Politics, 1(1), 181-195.

Chilton, P. (2004) Analysing political discourse: Theory and practice. Taylor \& Francis e-Library.

Cohen, T. (2013, October 17) House approves bill to end shutdown. CNN International. Retrieved from http://www.cnn.com/2013/10/16/politics/shutdown showdown/index.html?utm_source=feedburner \&utm_medium=feed\&ut_campaign=Feed $\% 3 \mathrm{~A}+\mathrm{rss} \% 2 \mathrm{Fcnn}$ _allpolitics $+\% 28 \mathrm{RSS} \% 3 \mathrm{~A}+\mathrm{Politics} \% 29$.

Cook, G. (2011) Discourse Analysis. In Simpson, J. (ed.) The Routledge Handbook of Applied Linguistics. New York: Routledge, 431-445.

Culpeper, J. (1996) Towards an anatomy of impoliteness. Journal of Pragmatics, 25, 349-367.

Culpeper, J. (2005) Impoliteness and the weakest link. Journal of Politeness Research, 1(1), 35-72.

Culpeper J. (2013) Impoliteness: Questions and answers. In Jamet D. \& M. Jobert (eds.) Aspects of Linguistic Impoliteness. Newcastle-upon-Tyne: Cambridge Scholars Publishing, 2-16.

Culpeper, J., Bousfield, D., \& Wichmann, A. (2003) Impoliteness revisited: With special reference to dynamic and prosodic aspects. Journal of Pragmatics, 35 (10/11), 1545-1579.

de Marlangeon, S. K. (2018) Fustigation impoliteness, emotions and extimacy in Argentine Media celebrities. Russian Journal of Linguistics, 22(1), 161-174.

Dunmire, P. L. (2012) Political discourse analysis: Exploring the language of politics and the politics of language. Language and Linguistics Compass, 6(11), 735-751.

Espo, D. (2013, September 30) Republican unity frays as government shutdown looms. Hoffington Post (AOL). Associated Press. Retrieved from http://www.huffingtonpost.com/2013/09/30/ republicans-governmentsh_n_4019692.html. 
Farmer, B. R. (2006) American political ideologies: an introduction to the major systems of thought in the 21st century. Jefferson, NC: McFarland \& Company.

Garcia-Pastor, M. D. (2002) Face aggravation, mitigation, and unofficial power in a political campaign debate. In Walton D. \& D. Scheu (eds.) Culture and Power. Bern: Peter Lang, 347-367.

Goffman, E. (1967) Interaction ritual: Essays on face-to-face behavior. New York: Doubleday.

Gornostaeva, A. A. (2016) The place of irony in the speech portrait of a modern politician. Russian Journal of Linguistics, 20(1), 57-76.

Government shutdowns in the United States (n.d.) In Wikipedia. Retrieved May 25, 2018, from https://en.wikipedia.org/wiki/Government_shutdowns_in_the_United_States.

Grice, H. P. (1975) Logic and conversation. In Cole P. \& J. Morgan (eds.) Speech Acts [Syntax and semantics 3]. New York: Academic Press, 41-58.

Grigsby, E. (2008) Analyzing politics: An introduction to political science. Florence: Cengage Learning.

Harris, S., Grainger, K., \& Mullany, L. (2006) The pragmatics of political apologies. Discourse and Society, 17(6), 715-737.

Hinton, P. R., Brownlow, Ch., McMurray, I., \& Cozens, B. (2004) SPSS explained. London and New York: Routledge: Taylor and Francis Group.

Holmes, J. Marra, M., \& Schnurr, S. (2008) Impoliteness and ethnicity: Māori and Pākehā discourse in New Zealand workplaces. Journal of Politeness Research: Language, Behaviour, Culture, 4(2): $193-219$.

Holmes, J., \& Schnurr. S. (2005) Politeness, humour and gender in the workplace: Negotiating norms and identifying contestation. Journal of Politeness Research 1(1), 121-149.

Institute of Medicine. Committee on consequences of uninsurance (2004, January 13) Insuring America's health: principles and recommendations. Washington, DC: National Academies Press.

Jamet, D., \& Jobert, M. (Eds.). (2013) Aspects of linguistic impoliteness. Cambridge Scholars Publishing.

Levy, J. (2006) The state after statism: New state activities in the age of liberalization. Florence: Harvard University Press.

Locher, M. A., \& Watts, R. J. (2005) Politeness theory and relational work. Journal of Politeness Research. Language, Behaviour, Culture, 1(1), 9-33.

Lorenzo-Dus, N. (2009) "You're barking mad, I'm out": Impoliteness and broadcast talk. Journal of Politeness Research, 5, 159-187.

Maalej, Z. A. (2012) The 'Jasmine Revolt' has made the 'Arab Spring': A critical discourse analysis of the last three political speeches of the ousted president of Tunisia. Discourse \& Society, 23(6), 679-700.

Maynard, S. K. (1994) Images of Involvement and Integrity: Rhetorical Style of a Japanese Politician. Discourse and Society, 5(2), 233-261.

Mikis, S. M., \& Melieur, J. M. (2005) The great society and the high tide of liberalism. Amherst, MA: The University of Massachusetts Press.

Mills, S. (2003) Gender and politeness. Cambridge: Cambridge University Press.

Mirhosseini, M., Mardanshahi, M., \& Dowlatabadi, H. (2017) Impoliteness strategies based on Culpeper's model: An analysis of gender differences between two characters in the movie Mother. Journal of Applied Linguistics and Language Research, 4(3), 221-238.

Mirzaei, A., Eslami, Z. R., \& Safari, F. (2017) Exploring rhetorical-discursive practices of Rouhani's presidential campaign and victory of his prudence-and-hope key: A discourse of persuasion. Russian Journal of Linguistics, 21(1), 161-182. 
Murphy, J. (2014) (Im)politeness during Prime Ministers Questions in the U.K. Parliament. Pragmatics and Society, 5(1), 76-104.

National Research Council, \& Committee on Population (2013) US health in international perspective: Shorter lives, poorer health. National Academies Press.

Oddo, J. (2011) War legitimation: representing 'us' and 'them' in four presidential addresses. Discourse \& Society, 22(3), 1-28.

Okulska, U. \& Cap, P. (2010) Analysis of political discourse: landmarks, challenges, and prospects. In Okulska U. \& P. Cap (eds.) Perspectives in Politics and Discourse. Amsterdam: John Bejamins, 3-22.

P'erez de Ayala, S. (2001) FTAs and Erskine May: Conflicting needs? Politeness in question time. Journal of Pragmatics, 33(2), 143-169.

Pelinka, A. (2007) Language as a political category: the viewpoint of political science. Journal of Language \& Politics 6(1), 129-43.

Peters, J. W. (2011, January 20) Conservatives' aggressive Ad campaign seeks to cast doubt on health law. New York Times. Retrieved from http://www.nytimes.com/2013/07/07/us/politics/ conservatives aggressive ad-campaign-seeks-to-cast-doubt-on-health-law.html?_r=0.

Public Law (2010, March 23) 111th United States Congress. Washington, DC: United States Government Printing Office. Retrieved from http://www.gpo.gov/fdsys/granule/PLAW-111publ148/ PLAW 111publ148/content-detail.html.

Toddington, R. S. (2015) Impoliteness as a vehicle for humour in dramatic discourse (Doctoral dissertation, University of Central Lancashire). Retrieved from http://clok.uclan.ac.uk/12121/1/ Toddington\%20Rachel\%20Final\%20e-Thesis\%20\%28Master\%20Copy\%29.pdf.

United States Congress (n.d.) In Wikipedia. Retrieved May 25, 2018, from https://en.wikipedia.org/ wiki/United_States_Congress.

Van Dijk, T. A. (1997) What is political discourse analysis. Belgian journal of linguistics, 11(1), $11-52$.

Watts, R. J. (2003) Politeness. Cambridge: Cambridge University Press.

Wilper, A. P., Woolhandler, S., Lasser, K. E., McCormick, D., Bor, D. H., \& Himmelstein, D. U. (2009) Health insurance and mortality in adults. American Journal of Public Health, 99(12), $2289-2295$.

Zaripov, R. I. (2014) Manipulation impact through metaphors in political discourse. Russian Journal of Linguistics, (2), 145-158.

\section{Article history:}

Received: 10 May 2018

Revised: 23 July 2018

Accepted: 15 September 2018

\section{История статьи:}

Дата поступления в редакцию: 10 мая 2018

Дата принятия к печати: 15 сентября 2018

\section{For citation:}

Alemi, Minoo and Latifi, Ashkan (2019). The Realization of Impoliteness in Arguments between the Democrats and Republicans over the Government Shutdown Issue in the US. Russian Journal of Linguistics, 23 (1), 83 — 97. doi: 10.22363/2312-9182-2019-23-1-83-97. 


\section{Для цитирования:}

Alemi M., Latifi A. (2019). The Realization of Impoliteness in Arguments between the Democrats and Republicans over the Government Shutdown Issue in the US // Вестник Российского университета дружбы народов. Серия: Лингвистика = Russian Journal of Linguistics. 2019. T. 23. No. 1. C. 83 -97. doi: 10.22363/2312-9182-2019-23-1-83-97.

\section{Bionotes:}

MINOO ALEMI is Associate Professor of Applied Linguistics at Islamic Azad University, West Tehran Branch, and a post-doctoral associate at Sharif University of Technology (SUT), Iran. She is the associate editor of Applied Pragmatics (John Benjamins) and sits on the editorial/review boards of many journals. Her areas of interest include discourse analysis, interlanguage pragmatics, materials development, and robot-assisted language education.

Contact information: e-mail: Minooalemi2000@yahoo.com

ASHKAN LATIFI holds an MA in Applied Linguistics from Sharif University of Technology and is currently an MA student of Sociology at Bu-Ali Sina University. His areas of interest are neuropsychology, psycholinguistics, neurolinguistics, and sociolinguistics.

Contact information: e-mail: ashkan.latify@gmail.com

\section{Сведения об авторах:}

МИНУ АЛЕМИ - доцент кафедры английского языка как иностранного, гуманитарный факультет филиала Исламского университета Азад, научный сотрудник Технологического университета им. Шарифа, заместитель главного редактора журнала Applied Pragmatics (John Benjamins), член редколлегий нескольких международных научных периодических изданий. Сфера научных интересов: дискурс-анализ, межкультурная прагматика, разработка учебных материалов и роботизированное обучение языку.

Контактная информация: e-mail: Minooalemi2000@yahoo.com

АШКАН ЛАТИФИ - магистр прикладной лингвистики, Технологический университет им. Шарифа. Сфера научных интересов: нейропсихология, психолингвистика, нейролингвистика, социолингвистика.

Контактная информация: e-mail: ashkan.latify@gmail.com 